\title{
Quality of Life and Spirituality in Medical Students
}

\author{
Juliano de Trotta ${ }^{1}$, Sérgio Candido Kowalski ${ }^{2}$, Francisco Cenci Comin ${ }^{1}$, \\ Rafaela Chiuco Zeni ${ }^{1}$ \& Pedro Vinícius Jales de Araújo ${ }^{1}$ \\ ${ }^{1}$ Pontifical Catholic University of Paraná, School of Medicine, Curitiba, Paraná, Brazil \\ ${ }^{2}$ Federal University of Paraná, Department of Internal Medicine, Curitiba, Paraná, Brazil \\ Correspondence: Juliano de Trotta, School of Medicine, Pontifical Catholic University of Paraná, School of \\ Medicine, Curitiba, Paraná, Brazil. Tel: 55-(41)-99-501-9502.
}

Received: October 31, 2020 Accepted: December 12, 2020 Online Published: December 23, 2020

doi:10.5539/gjhs.v13n2p37 URL: https://doi.org/10.5539/gjhs.v13n2p37

\begin{abstract}
Quality of life is an eminently human condition that informs the perception of how the individual is in his life values, while spirituality and religiosity represent the connection with the sacred, the transcendental practices in the search for existential causes. Bringing these concepts to the academic environment can help in promoting health and better training for future medical professionals. The main objective of this study is to evaluate the relationship between quality of life and spirituality of medical students at a private university in the state of Paraná, Brazil. One hundred eighty-nine medical students answered three questionnaires (socio-demographic, WHOQOL-bref on quality of life, and DUREL spirituality) during the first and last year of graduation. In this study, we found that the general quality of life of medical students, according to the WHOQOL-bref scale, is regular (3.78), and there was no statistically significant difference in the general quality of life between the first and the last year of medical school. $(\mathrm{p}=0.156)$. The social and environmental domains leveraged the scores more than the physical and psychological domains in both groups. On the Durel scale, intrinsic religiosity (IR) stood out more than organized (OR) and non-organized (NOR) religiosity, with statistically significant differences $(p=0.018)$, which may imply that these students prefer to seek more in themselves, a harmony of life between their beliefs and their particular needs, internalizing existential and spiritual reflexes that are reflected in their behaviors and decisions.
\end{abstract}

Keywords: health and spirituality, health promotion, health promotion for undergraduate students, Quality of life, religiosity, spirituality

\section{Introduction}

The concept of quality of life emerged during the 1970s through the collaboration between the social, economics, humanities, and health sciences fields. From that moment on, this concept rapidly spread, becoming the focus of study in different areas of knowledge. Up to this day, however, quality of life remains without a precise definition, due to its high degree of complexity and to the divergence of opinions (Chazan, 2013).

It is known that the perception of the quality of life is an eminently human condition and that it is linked to the degree of satisfaction found in the social, family, work, environmental and loving environments, forming a personal and existential aesthetic of well-being (Minayo et al., 2000).

The World Health Organization (WHO, 1990: 01), in the 1990s, created the Quality Of Life (QOL) group, which formulated a general concept of quality of life, defined as: "an individual's perception of their position in life in the context of the culture and value systems in which they live and in relation to their goals, expectations, standards and concerns" and created an instrument called WOQHOL-100, which later got a shortened version called WOQHOL-bref, simplifying the form filling and maintaining satisfactory psychometric characteristics (Fleck, 2000; WHOQOL-bref, 1996).

Therefore, the concept of quality of life can be assessed qualitatively and quantitatively using statistical analysis tools. This aspect contributes to the solidification of the WHOQOL-bref as an instrument for assessing quality of life, highlighting the research carried out in Brazil, which is the country with the highest number of published articles using this instrument in their methodology (Kluthcovsky \& Kluthcovsky, 2009; Chazan \& Campos, 2013).

Referring to spirituality, it is understood as the personal search for the reason of living within the transcendental. It 
is the search for the Sacred and for the answers to existential questions, which leads to religiosity and results in the development of rituals, beliefs, and dogmas (Aquino, 2009).

In recent years, there was an increase in the investigation of the relationship between religiosity and physical or mental health. In this sense, several authors pointed out that religiosity/spirituality acts as a protective factor against the development of mental disorders, such as depression, anxiety, psychoactive substance use and risky behavior, (Abdala et al., 2010; Moreira-Alemida \& Lucchetti, 2016; Koenig, 2012) contributing to the improvement of the individual's quality of life, sense of well-being, and social support. (Melo et al., 2015) Thus, several factors associated with religiosity can contribute to the increase of resilience and reduce mental impairment, such as the adoption of healthy lifestyles, access to social support, and the system of beliefs that support the reduction of psychological suffering (Pargament, 1997; Alvarez et al., 2016; Strelhow \& Sarriera, 2018).

In Brazil, recent data indicated that $95 \%$ of the population affirmed to have a religion; therefore, religiosity is a very important aspect of the Brazilian lifestyle. This data increases the interest in studying religiosity and its relation to physical and mental health. However, there is a relative lack of instruments developed to measure different dimensions of religiosity, and the Duke University Religion Index is the most widely used (Taunay et al., 2012).

The academic environment has been the focus of numerous discussions due to its constant changes, especially regarding the growing number of university students, resulting in more significant heterogeneity and respecting the characteristics of the group's individuals, such as their social class, gender, age, work situation, goals, and expectations, among other aspects (Schleich, 2006; Tassini et al., 2017).

Analyzing the entire university environment, the medical school is known to be an environment associated with countless factors related to stress that negatively impact academic performance as well as both physical and emotional health of students. Embarking this journey is accompanied by several challenges, which are present since the selection process - extremely competitive and with a significantly high cut-off point. Furthermore, there is an implicit social pressure on undergraduate students about the expected economic success in their future, which could lead to an over-expectation and, consequently, frustration (Moutinho et al., 2017).

The trajectory of the university student during medical training entails full-time commitment and responsibility regarding academic tasks. Long study and working hours, inadequate learning environments, sleep deprivation, as well as constant changes in the student's personal daily life are very common during this period (Moutinho et al., 2017) These aspects, associated with a lack of factors that promote quality of life, can lead to stress levels that negatively impact the physical, mental, and emotional health of students, compromising their academic performance and social well-being (Dyrbye, Thomas, \& Shanafelt, 2006).

The mental health of medical students is an area of increasing worldwide concern as this population has been shown to be particularly prone to depression, anxiety, and stress mainly triggered by academic pressure, obstacles to achieving their goals, environmental changes, and life challenges - such as the transition from school to university and the change in role from student to experienced doctor (Saravanan \& Wilks, 2014).

In Europe, around $30 \%$ of medical students are diagnosed with depression or anxiety, a rate similar to that obtained by Brazilian studies, in which 20 to $50 \%$ of medical students were found to have mood disorders. Medical students also have higher rates of depression and suicidal ideation than the general population, representing a major challenge to the training of future doctors (Moutinho et al., 2017).

In this regard, although many studies point to an association of religious / spiritual beliefs with mental health, physical health, and quality of life and other investigations have evaluated religiosity and views of medical students on this subject, few studies have specifically investigated the association between mental health and beliefs in medical education (Moutinho et al., 2017). This environment was chosen to be the focus of our study due to these characteristics.

Thus, our study aims to determine the quality of life of medical students in four domains (physical, psychological, social relationships, and environmental), in order to understand the spirituality and religiosity of these students and to analyze not only the relationship between quality of life and spirituality but also the transformation of this relationship during medical training.

\section{Material and Methodology}

This is an exploratory, cross-sectional, and descriptive study, with a quantitative approach, allowing a greater approximation of the daily life and of the experiences lived by the investigated subjects.

The study was carried out with regular students of the first and final years of the undergraduate medical course of 
a private institution in Curitiba, the capital city of the State of Parana, Brazil. The data collection was performed using an online questionnaire which was elaborated based on socio-demographic questions, as well as on the Durel University Religion Index scale and the WHOQOL-bref form, using the platform Google Forms, with access through electronic devices (computers, tablets, and smartphones with access via electronic mail).

The inclusion criteria were: undergraduate students registered and active at the medical course. Exclusion criteria were: students who did not sign the free and informed consent form, who already had previously graduated in another course, and who were engaged in any daily paid employment when the questionnaire was applied, except for those who were engaged in research, peer tutoring program or medical internship.

Students who had extensive external commitments, such as paid work or other conditions unrelated to medical course, were excluded because these responsibilities can affect students' perception of quality of life, beyond the demands of graduation (Velarde-Jurado \& Avila-Figueroa, 2002; Rossi, Meurs, \& Perrewé, 2013).

The DUREL scale has five items that describe three domains of religiosity/spirituality (RE), which are known for its correlation with health issues: organizational religiosity (OR), which is associated with the frequency of religious meetings; non-organizational religiosity (NOR), which is related to the frequency of private religious activities; and intrinsic religiosity (IR), which regards the search for internalization and the full experience of religiosity as the main individual objective (Moreira-Almeida et al., 2008; Taunay et al., 2012).

In the analysis of DUREL's spirituality and religiosity scale, the scores were classified and interpreted as low (values $<4$ ) or high (values $\geq 4$ ) for the standard parameters of organizational religiosity (OR) and non-organizational religiosity (NOR). Consisting of 3 questions, the intrinsic religiosity score ranges from 3 to 15 ; scores lower than 10 were the parameter related to low religiosity and spirituality and scores higher than or equal to 10 were the parameter to high religiosity and spirituality (Fonseca, 2019; Stroppa \& Moreira-Almeida, 2013).

The WHOQOL-bref form, on the other hand, consists of 26 questions, two of which are about the quality of life self-assessment, and the other 24 questions represent each aspect of the WHOQOL-100. Thus, the results of the WHOQOL-bref consist of a general result and four other domains: Physical, Psychological, Social relationships, and Environmental (Fleck et al., 1999; Loures \& Porto, 2009). The data obtained were submitted to the form guidelines. The parameters to analyze the results of the arithmetic means of the WOQHOL were the following: poor or low quality of life for scores between 1 and 2.9; moderate for scores between 3 to 3.9; high for scores between 4 and 4.9; and excellent when the score was 5 .

The data analysis was performed using both the Excel ${ }^{\circledR}$ and SPSS software. The Levene test was performed to assess the equality of variances, and the analyses of the statistical significance parameters were obtained by the Student's t-test with a p-value $<0.05$. This research had the university's consent and was approved by the ethics committee under the CAAE number 23054819.7.0000.0020.

\section{Results}

A total of 189 medical students participated in the study, who were in the first or the final year of medical school. Nine volunteers were excluded from the study according to the exclusion criteria, since two of them did not agree to sign the free and informed consent form, and the other seven had already graduated in another course or were engaged in any external commitment. Therefore, 180 students remained in our study, 94 of which were in the first year of medicine, and 86 were in the final (sixth) year.

The socio-demographic data (Table 1) showed a predominantly female population of 137 participants (76.11\%), with an average age of 21.9 years, and the majority of the respondents, a total of 134 (74.44\%), lived with their family or friends. Regarding life habits, the vast majority reported alcohol intake, but $148(82.22 \%)$ reported an infrequent intake. $172(95.56 \%)$ participants were non-smokers. Regarding physical activity, 23 (12.78\%) participants were sedentary, while $93(51.67 \%)$ reported practicing sporadic or irregular physical activity, and 64 (35.56\%) affirmed to practice physical activity regularly. This data meets the results of the body mass index (BMI), in which 143 (79.44\%) participants scored within the normal range (Table 1). 
Table 1. Socio-demographic information of the studied sample

\begin{tabular}{|c|c|c|c|c|c|c|c|}
\hline \multirow{2}{*}{ Variables } & \multirow{2}{*}{ Descriptors } & \multicolumn{2}{|c|}{$1^{\text {st }}$ year } & \multicolumn{2}{|c|}{$6^{\text {th }}$ year } & \multicolumn{2}{|c|}{ Total } \\
\hline & & Value & $\%$ & Value & $\%$ & Value & $\%$ \\
\hline Universe & Participants & 94 & 49.73 & 86 & 45.5 & 180 & 100 \\
\hline \multirow{2}{*}{ Gender } & Female & 70 & 74.47 & 67 & 77.9 & 137 & 76.11 \\
\hline & Male & 24 & 25.53 & 19 & 22.09 & 43 & 23.88 \\
\hline \multirow{2}{*}{ Age } & Arithmetic average & 19.6 & & 24.5 & & 21.88 & \\
\hline & Live alone & 18 & 19.15 & 28 & 32.56 & 46 & 25.56 \\
\hline Housemate & Live with family/friends & 76 & 80.85 & 58 & 67.44 & 134 & 74.44 \\
\hline \multirow{3}{*}{ Alcohol intake } & Absent & 13 & 13.83 & 13 & 15.11 & 26 & 14.44 \\
\hline & Irregular & 80 & 85.11 & 68 & 79.07 & 148 & 82.22 \\
\hline & Abuse & 1 & 1.09 & 5 & 5.81 & 6 & 3.34 \\
\hline \multirow{2}{*}{ Smoking } & Non-smoker & 91 & 96.8 & 81 & 94.18 & 172 & 95.56 \\
\hline & Smoker & 3 & 3.19 & 5 & 5.81 & 8 & 4.44 \\
\hline \multirow{3}{*}{ Physical activity } & Sedentary & 14 & 14.89 & 9 & 10.46 & 23 & 12.78 \\
\hline & Irregular exercise & 65 & 69.14 & 28 & 32.55 & 93 & 51.67 \\
\hline & Regular exercise & 15 & 15.95 & 49 & 56.97 & 64 & 35.56 \\
\hline \multirow{4}{*}{ Body mass index } & Low weight & 4 & 4.26 & 5 & 5.81 & 9 & 5.00 \\
\hline & Normal weight & 79 & 84.04 & 64 & 74.42 & 143 & 79.44 \\
\hline & Overweight & 10 & 10.64 & 11 & 12.79 & 21 & 11.67 \\
\hline & Obesity & 1 & 1.16 & 6 & 6.98 & 7 & 3.89 \\
\hline
\end{tabular}

Source: The Authors, 2020.

When asked about their general health status, the majority of the students $133(73.89 \%)$ reported being in good or in excellent condition; however, $91(50.56 \%)$ reported to have some disease. The most frequently reported diseases were: anxiety $43(23.9 \%)$, depression $18(10 \%)$, asthma $16(8.9 \%)$, thyroid disease $15(8.3 \%)$, back pain $15(8.3 \%)$, obesity $7(3.9 \%)$, dyslipidemia $6(3.3 \%)$, and joint pain $4(2.2 \%)$. Furthermore, $59(32.78 \%)$ reported being in treatment and using regular medications and $100(56.06 \%)$ students reported having had negative feelings in the last two weeks before the survey (Table 2).

Table 2. Health condition and emotional moment of the student

\begin{tabular}{|c|c|c|c|c|c|c|c|}
\hline \multirow{2}{*}{ Variables } & \multirow{2}{*}{ Descriptors } & \multicolumn{2}{|c|}{$1^{\text {st }}$ year } & \multicolumn{2}{|c|}{$6^{\text {th }}$ year } & \multicolumn{2}{|c|}{ Total } \\
\hline & & Value & $\%$ & Value & $\%$ & Value & $\%$ \\
\hline \multirow{3}{*}{ Current health condition } & Good or great & 74 & 78.72 & 59 & 68.60 & 133 & 73.89 \\
\hline & Regular & 17 & 18.09 & 23 & 26.74 & 40 & 22.22 \\
\hline & Bad or terrible & 3 & 3.19 & 4 & 4.66 & 7 & 3.89 \\
\hline \multirow{2}{*}{ Presence ofdisease } & Yes & 37 & 39.36 & 54 & 62.79 & 91 & 50.56 \\
\hline & No & 57 & 60.64 & 32 & 37.21 & 89 & 49.44 \\
\hline \multirow{2}{*}{ Regular use of medications } & Yes & 20 & 21.28 & 39 & 45.35 & 59 & 32.78 \\
\hline & No & 74 & 78.72 & 47 & 54.65 & 121 & 67.22 \\
\hline \multirow[t]{2}{*}{ Negative feelings } & $\begin{array}{l}\text { Frequent or } \\
\text { very frequent }\end{array}$ & 50 & 53.20 & 50 & 58.14 & 100 & 55.56 \\
\hline & None or rarely & 44 & 46.8 & 36 & 41.86 & 80 & 44.44 \\
\hline
\end{tabular}




\begin{tabular}{|c|c|c|c|c|c|c|c|}
\hline \multirow{2}{*}{ Charity or volunteer services } & Do & 38 & 40.43 & 35 & 40.70 & 73 & 40.56 \\
\hline & Do not do & 56 & 59.57 & 51 & 59.30 & 107 & 59.44 \\
\hline \multirow{2}{*}{$\begin{array}{l}\text { Believe that spirituality and religiosity influence in } \\
\text { treatment }\end{array}$} & Yes & 79 & 84.04 & 83 & 96.51 & 162 & 90.00 \\
\hline & No & 15 & 15.96 & 3 & 3.49 & 18 & 10.00 \\
\hline
\end{tabular}

Source: The Authors, 2020.

The general classification of medical students QOF was regular (3.78). Better averages were observed in students of the first year of college (3.84) in comparison to those in the final year (3.73); however, the significance test showed no statistically significant difference between both groups.

The social and environmental domains leveraged the medical students' quality of life scores, represented in Graph 1 as a percentage of participation.

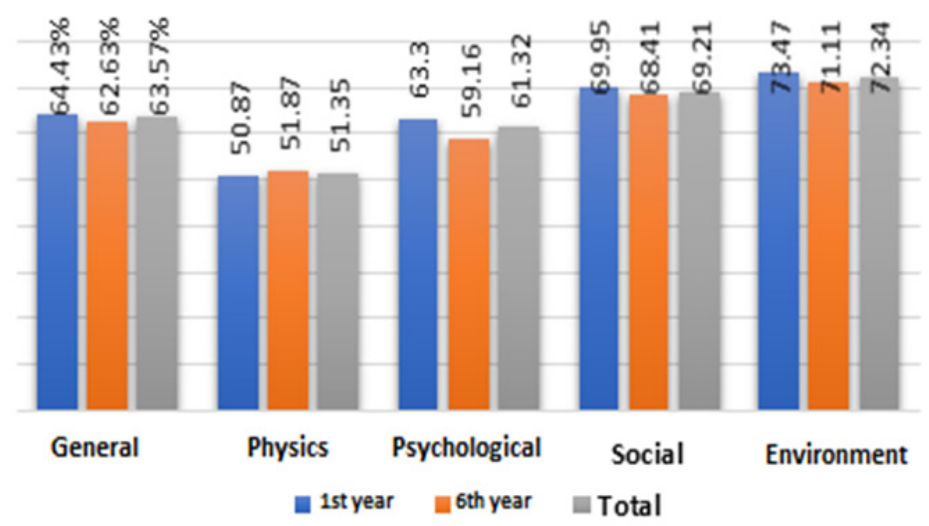

Graphic 1. Relation of the domain values in percentage to the student's graduation year

Source: The Authors, 2020.

In the total analysis of the students, among the 26 facets of each domain, mobility, home environment, health care, and new information and skills contributed $80 \%$ or more to increase the students' quality of life (Graphic 2).

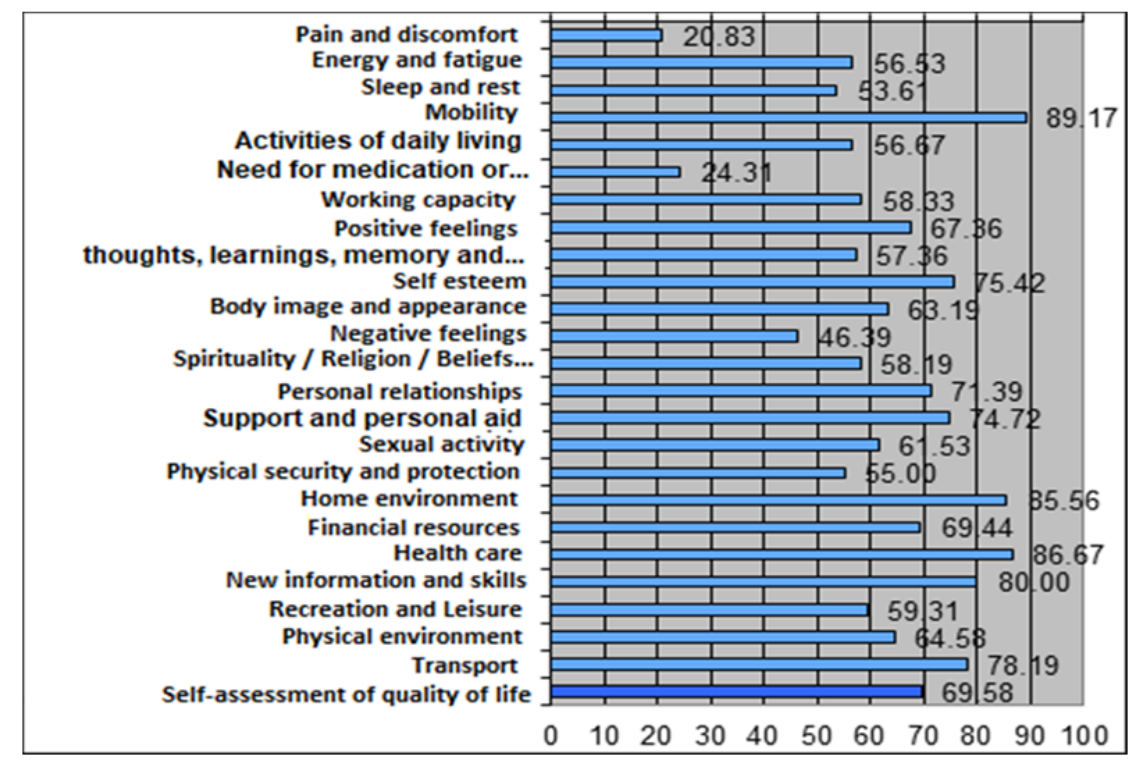

Graphic 2. General analysis of the results of the WOQHOL scale

Source: The Authors, 2020. 
The total sample of students presented low religiosity and low spirituality scores in all of the DUREL scale dimensions, with OR $(2.63 \pm 1.46)$, NOR $(2.73 \pm 1.74)$ and IR $(8.91 \pm 3.81)$. However, the arithmetic averages of the final-year medical students were higher than those of the first year. There was a statistically significant difference in the dimension of Intrinsic Religiosity (IR), showing that the final-year students presented higher religiosity, as shown in table 3 .

Table 3. Year of medical school by the DUREL scale

\begin{tabular}{|c|c|c|c|c|c|c|c|c|}
\hline $\begin{array}{l}\text { DUREL } \\
\text { scale }\end{array}$ & $\begin{array}{l}\text { Graduation } \\
\text { year }\end{array}$ & Sample & Mean & $\begin{array}{l}\text { Standard } \\
\text { deviation }\end{array}$ & Median & Minimum & Maximum & $P$ value \\
\hline \multirow{3}{*}{ OR } & $1^{\text {st }}$-year & 94 & 2.53 & \pm 1.46 & 2.00 & 1 & 6 & \multirow{3}{*}{0.334} \\
\hline & $6^{\text {th }}$-year & 86 & 2.74 & \pm 1.48 & 3.00 & 1 & 6 & \\
\hline & Total & 180 & 2.63 & \pm 1.46 & 2.50 & 1 & 6 & \\
\hline \multirow{3}{*}{ NOR } & $1^{\text {st }}$-year & 94 & 2.55 & \pm 1.73 & 2.00 & 1 & 6 & \multirow{3}{*}{0.146} \\
\hline & $6^{\text {th }}$-year & 86 & 2.93 & \pm 1.73 & 2.00 & 1 & 6 & \\
\hline & Total & 180 & 2.73 & \pm 1.74 & 2.00 & 1 & 6 & \\
\hline \multirow{3}{*}{ IR } & $1^{\text {st }}$-year & 94 & 8.27 & \pm 3.69 & 8.00 & 3 & 15 & \multirow{3}{*}{0.018} \\
\hline & $6^{\text {th }}$-year & 86 & 9.60 & \pm 3.84 & 11.00 & 3 & 15 & \\
\hline & Total & 180 & 8.91 & \pm 3.81 & 10.00 & 3 & 15 & \\
\hline
\end{tabular}

Source: The Authors, 2020.

NOTE. OR: Organizational religiosity; NOR: Non-organizational religiosity; IR: Intrinsic religiosity.

We observed statistically significant differences in the comparison of the relation between general quality of life and the averages of the socio-demographic variables between first-year and final-year students. The differences can be seen in the following aspects: (1) body mass index; (2) physical activity; (3) self-perception of current health condition; (4) presence of a disease; (5) regular use of medications; (6) perception of negative feelings; (7) presence of psychosomatic symptoms and (8) parallel activities. Regarding medical students' quality of life, other variables such as religiosity and spirituality (OR, NOR, and IR), gender, age, year of graduation, home-sharing, voluntary services, smoking, and alcohol consumption showed no statistically significant difference in the samples (Table 4).

Table 4. Comparison of the variables' means to the medical students' general quality of life.

\begin{tabular}{|c|c|c|c|c|c|}
\hline \multirow{2}{*}{$\begin{array}{l}\text { General perception of } \\
\text { quality of life - WOQHOL } \\
\begin{array}{l}\text { Statistically } \\
\text { variables }\end{array}\end{array}$} & \multicolumn{2}{|c|}{$\begin{array}{l}\text { Bad or regular } \\
\text { number } 76(42.22 \%)\end{array}$} & \multicolumn{2}{|c|}{$\begin{array}{l}\text { Good or excellent } \\
\text { number } 104(57.78 \%)\end{array}$} & \multirow{2}{*}{$\mathbf{P}$} \\
\hline & mean & standard error of mean & mean & standard error of mean & \\
\hline BMI & 23.05 & 0.435 & 21.60 & 0.239 & 0.004 \\
\hline Physical activity & 2.22 & 0.085 & 2.57 & 0.064 & 0.001 \\
\hline Current health condition & 2.38 & 0.072 & 2.93 & 0.038 & $<0.001$ \\
\hline Regular use of medications & 1.43 & 0.057 & 1.25 & 0.043 & 0.011 \\
\hline Presence of disease & 1.67 & 0.054 & 1.38 & 0.048 & $<0.001$ \\
\hline Perception of feelings & 1.76 & 0.049 & 1.40 & 0.048 & $<0.001$ \\
\hline $\begin{array}{l}\text { Presence of psychosomatic } \\
\text { symptoms }\end{array}$ & 1.99 & 0.013 & 1.85 & 0.036 & 0.001 \\
\hline Parallel activities & 1.58 & 0.057 & 1.74 & 0.043 & 0.025 \\
\hline
\end{tabular}

Source: The Authors, 2020. 


\section{Discussion}

College admission is followed by significant changes in the student's routine, bringing the need for them to adapt not only to a new scenario and new activities but also to the challenge of new social relationships. Another aspect of the academic environment is commonly the expectations and personal demands regarding their insertion in the job market, as well as their satisfaction with the choice of a future profession (Silva \& Heleno, 2012).

The appraisal of quality of life occurs in a complex way, as it must involve subjective parameters of well-being, happiness, love, pleasure, personal fulfillment, and accomplishment of basic, economic, and social needs inherent in the society in which the student lives (Minayo, Hartz, \& Buss, 2000). For this reason, the instrument used in data collection contemplates the most diverse aspects with regard to the physical, psychological, social, and environmental domains, seeking to deepen each one of them, in order to decrease or increase the quantification of the quality of life score (Fleck et al., 2000).

According to the values observed for the total sample of students, the analysis of the t-test showed that those students who have lower BMI and who practice physical activity more often, also have better self-perception of their health status, fewer reports of diseases, use of fewer medications, are more engaged in parallel activities and, finally, have less negative feelings in their lives, therefore presenting a higher level of quality of life $(p<0.05)$.

There was no statistical difference in the quality of life between the first year and the final year of the medical course, nor in the following domains: physical, psychological, social, and environmental. However, we observed that both the Environmental domain $3.89(72.34 \%)$ and Social relationships domain $3.76(69.21 \%)$ produced a higher increase in the general percentages of quality of life in comparison to the Physical dimension 3.68 (61.32\%) and the Psychological 3.50 (51.35\%).

The Environmental domain usually is the one that, among all of the studied domains, less affects the results (Alves, 2010). For example, the study by Ramos-Dias et al. (2000) evaluated 100 students from a Brazilian university in the state of São Paulo and demonstrated that although the Environmental domain had a lower score than the other domains, it was very close to the other scores. In contrast, in a Chinese study, Zhang et al. (2012) showed that the Environmental domain score was significantly lower than the other domains.

However, in our research, this domain leveraged the students' scores of quality of life in both first and final years of college. Similarly, the results found in Arabian studies by Naseem et al. (2016) and Malibary et al. (2019), and in Brazilian study by Pagnin and Queiroz (2015) demonstrated higher values for the Environmental domain and lower values for the Psychological domain.

The Environmental dimension was prevalent in our study, probably because our research was made in a private university, in which the majority of students have financial resources and broad family support, increasing the items that compose this domain, such as security, home environment, financial resources, transportation, leisure opportunities, and physical environment, presenting more sensibility to the socioeconomic relationships in comparison to the other domains.

In agreement with the study by Pagnin e Queiroz (2015), the Psychological domain presented the lowest averages in our study, which represents vulnerability regarding personal feelings, thoughts, learning, memory and concentration, self-esteem, body image, appearance, and beliefs, perhaps due to attending undergraduate courses, a time of the student's life that has high demands and requires personal transformations. A study by Esperidão (2004) reported one of the explanations for this fact: the college does not value aspects related to the emotional strengthening of undergraduated health students, minimizing and disregarding several situations that generate discomfort and anxiety to these students, contributing even more to this weakness in the Psychological domain (Esperidão \& Munari, 2004)

In this context, studies indicate that academics who are under the influence of a society considered economically and politically stable tend to have higher scores in the Psychological domain (Malibary et al., 2019). However, our study was conducted in the beginning of the COVID 19 pandemic, a moment of instability that caused lack of perspective on the future, suspension of academic practices and group experiences, and decrease of the student self-esteem - especially to those who were about to enter the labor market, contributing even more to lower grades in Psychological dimension (Eurich \& Kluthcovsky, 2008).

Other investigations determined that the time required for studying, the pressure to learn, the demand for high performance, the large amount of new information, the lack of time to do social activities, and the contact with death and sick people are the causes for the onset of depressive symptoms among medical students. Stress, anxiety, and depression are symptoms that can directly affect the quality of life of future doctors (Bampi et al., 2013; Silva $\&$ Heleno, 2018). These studies are in agreement with the data that we found in this research, in which the lowest 
scores belonged to the Physical and Psychological dimensions.

We also observed higher values for intrinsic religiosity in final-year medical students in comparison to first-year students, with a statistically significant difference between both groups. Intrinsic religiosity refers to fully experiencing religiosity and seeking to internalize feelings, thus a broader and more intense concept of religiosity. This data evidenced that this type of religiosity is developed and internalized by medical students during their undergraduate period.

Moreover, many students believe that spirituality can positively influence patient health (Lucchetti et al., 2013). Studies demonstrated that people who have higher spirituality and religiosity also have greater psychological well-being and fewer depressive episodes, hypertensive crises, and surgical complications (Costa et al., 2019; Espinha et al., 2013). Therefore, the usual practical experience of final-year medical students can contribute to create pronounced spiritual beliefs.

Some situations in this study may be due to specific conditions, such as the environment in which this study was carried out, which included only one private university that has institutional religious precepts. This aspect must be taken into account as a limitation in the analysis of the results.

\section{Conclusion}

We conclude in this study that the general quality of life of medical students, according to the WHOQOL-BREF scale, is regular (3.78), and there was no statistically significant difference in the general quality of life between the first and last years of medical school $(\mathrm{p}=0.156)$.

Intrinsic religiosity (IR) was statistically significant in relation to organized religiosity (OR) and non-organized religiosity (NOR), and the last year of medical school presented the highest means, which may imply that these students prefer to seek more in themselves, a life harmony between their beliefs and their particular needs, internalizing existential and spiritual reflections that are reflected on their behaviors and decisions.

Accordingly, $90 \%$ of medical students state to believe that spirituality/religiosity, somehow, influences the clinical evolution of a patient and the treatment of pathologies. Moreover, $61.7 \%$ of the students stated that they feel the presence of God or something similar, and only $44.63 \%$ have experienced spirituality and religiosity in their daily life. This shows that, despite the belief in the relationship between spirituality and health, there is still a lack of individual's internalization of spiritual reflections and of the development of these concepts in the training of future doctors.

Finally, this research meets other studies that demonstrate the importance of developing quality of life, stimulating reasoned spirituality/religiosity, and clarifying the interaction of these factors with the individual's health (Rosa, 2012; Bampi, 2013; Freitas, 2018; Rosmarin, 2020). We propose the reflection on the possibility of expanding the external and internal policies of universities in order to improve the professional training and, in addition, promote the improvement of quality of life and of spiritual development in students, bringing a broad social benefit, not only for the student but also for all those who will be their patients in the future.

\section{Competing Interests Statement}

The authors declare that there are no competing or potential conflicts of interest.

\section{References}

Abdala, G. A., Rodrigues, W. G., Torres, A., Rios, M. C., \& Brasil, M. S. A. (2010). A Religiosidade/Espiritualidade Como Influência Positiva Na Abstinência, Redução E/Ou Abandono Do Uso De Drogas. Revista De Estudos Da Religião, Março, 77-98.

Alvarez, J. S., Goldraich, L. A., Nunes, A. H., Zandavalli, M. C. B., Zandavalli, R. B., Belli, K. C., ..., Clausell, N. (2016). Association between spirituality and adherence to management in outpatients with heart failure. Arquivos brasileiros de cardiologia, 106(6), 491-501. https://doi.org/10.5935/abc.20160076

Aquino, T. A. A. D., Silva, J. P. D., Figueirêdo, A. T. B. D., Dourado, É. T. S., \& Farias, E. C. S. D. (2011). Avaliação de uma proposta de prevenção do vazio existencial com adolescentes. Psicologia: Ciência e Profissão, 31(1), 146-159. https://doi.org/10.1590/S1414-98932011000100013

Bampi, L. N. D. S., Baraldi, S., Guilhem, D., Pompeu, R. B., \& Campos, A. C. D. O. (2013). Percepção sobre qualidade de vida de estudantes de graduação em enfermagem. Revista Gaúcha de Enfermagem, 34(2), 125-132. https://doi.org/10.1590/S1983-14472013000200016

Chazan, A. C. S., \& Campos, M. R. (2013). Qualidade de vida de estudantes de medicina medida pelo WHOQOL-bref-UERJ, (2010). Revista Brasileira de Educação Médica, 37(3), 376-384. 
https://doi.org/10.1590/S0100-55022013000300010

Costa, M. S., Dantas, R. T., Alves, C. G. D. S., Ferreira, E. R., \& Silva, A. F. D. (2019). Espiritualidade e religiosidade: saberes de estudantes de medicina. Revista Bioética, 27(2), 350-358. https://doi.org/10.1590/1983-80422019272319

Dyrbye, L. N., Thomas, M. R., \& Shanafelt, T. D. (2006). Systematic review of depression, anxiety, and other indicators of psychological distress among U.S. and Canadian medical students. Acad Med., 81(4), 354-73. PMID: 16565188. https://doi.org/10.1097/00001888-200604000-00009

Esperidião, E., \& Munari, D. B. (2004). Holismo só na teoria: a trama de sentimentos do acadêmico de enfermagem sobre sua formação. Rev Esc Enferm USP, $38(3), \quad 332-40$. https://doi.org/10.1590/S0080-62342004000300012

Espinha, D. C. M., Camargo, S. M. D., Silva, S. P. Z., Pavelqueires, S., \& Lucchetti, G. (2013). Opinião dos estudantes de enfermagem sobre saúde, espiritualidade e religiosidade. Revista Gaúcha de Enfermagem, 34(4), 98-106. https://doi.org/10.1590/S1983-14472013000400013

Fleck, M. P. D. A. (2000). O instrumento de avaliação de qualidade de vida da Organização Mundial da Saúde (WHOQOL-100): características e perspectivas. Ciência \& Saúde Coletiva, 5, 33-38. https://doi.org/10.1590/S1413-81232000000100004

Fleck, M. P. D. A., Leal, O. F., Louzada, S., Xavier, M., Chachamovich, E., Vieira, G., ... \& Pinzon, V. (1999). Desenvolvimento da versão em português do instrumento de avaliação de qualidade de vida da OMS $\begin{array}{lllll}\text { (WHOQOL-100). Brazilian Journal of Psychiatry, } & \text { 21(1), }\end{array}$ https://doi.org/10.1590/S1516-44461999000100006

Fonseca, E. C. R. (2019). Avaliação da espiritualidade e religiosidade em pacientes com diabetes mellitus tipos 1 (Universidade Federal do Triângulo Mineiro). Retrieved from http://200.131.62.27/bitstream/tede/904/5/Dissert\%20Elvi\%20C\%20R\%20Fonseca.pdf

Freitas, A. C. M. D., Malheiros, R. M. D. M., Lourenço, B. D. S., Pinto, F. F., Souza, C. C. D., \& Almeida, A. C. L. (2018). Fatores intervenientes na qualidade de vida do estudante de enfermagem. Revista. enfermagem. UFPE online, 2376-2385. https://doi.org/10.5205/1981-8963-v12i9a230110p2376-2385-2018

Kluthcovsky, A. C. G., \& Kluthcovsky, F. A. (2009). O WHOQOL-bref, um instrumento para avaliar qualidade de vida: uma revisão sistemática. Revista de Psiquiatria do Rio Grande do Sul, 31(3), 0-0. https://doi.org/10.1590/S0101-81082009000400007

Koenig, H. G. (2012). Medicina, Religião E Saúde: O Encontro Da Ciência E Da Espiritulidade. Porto Alegre. Ed. L\&Pm.

Langame, A. D. P., Neto, J. A. C., Melo, L. N. B., Castelano, M. L., Cunha, M., \& Ferreira, R. E. (2016). Qualidade de vida do estudante universitário e o rendimento acadêmico. Revista Brasileira em Promoção da Saúde, 29(3), 313-325. https://doi.org/10.5020/18061230.2016.p313

Loures, M. C., \& Porto, C. C. (2009). A avaliação da qualidade de vida: guia para profissionais da saúde. Ciência \& Saúde Coletiva, 14(6), 2317-2318. https://doi.org/10.1590/S1413-81232009000600040

Minayo, M. C. S, Hartz, Z. M. A., \& Buss, P. M. (200). Qualidade De Vida E Saúde: Um Debate Necessário. Ciência \& Saúde Coletiva, 5(1), 18. https://doi.org/10.1590/S1413-81232000000100002

Lucchetti, G., Oliveira, L. R., Koenig, H. G., Leite, J. R., \& Lucchetti. A. L. G. (2013). Medical Students, Spirituality and Religiosity: Results From The Multicenter Study Sbrame. Bmc Med Educ., 13, 162. https://doi.org/10.1186/1472-6920-13-162

Malibary, H., Zagzoog, M. M., Banjari, M. A., Bamashmous, R. O., \& Omer, A. R. (2019). Quality Of Life (Qol) Among Medical Students In Saudi Arabia: A Study Using The Whoqol-Bref Instrument. Bmc Medical Education, 19(1), 344. https://doi.org/10.1186/s12909-019-1775-8

Minayo, M. C. D. S., Hartz, Z. M. D. A., \& Buss, P. M. (2000). Qualidade de vida e saúde: um debate necessário. Ciência \& saúde coletiva, 5, 7-18. https://doi.org/10.1590/S1413-81232000000100002

Melo, C. F., Sampaio, I. S., Souza, D. L. A., Pinto, N. S. (2015) Correlação entre religiosidade, espiritualidade e qualidade de vida: uma revisão de literatura. Estud. pesqui. psicol. [online], 15(2), 447-464. https://doi.org/10.12957/epp.2015.17650

Moreira-Almeida, A., Peres, M. F., Aloe, F., Neto, F. L., \& Koenig, H. G. (2008). Versão em português da Escala 
de Religiosidade da Duke: DUREL. Archives of Clinical Psychiatry, 35(1), 31-32. https://doi.org/10.1590/S0101-60832008000100006

Moreira-Almeida, A., \& Lucchetti, G. (2016) Panrama das pesquisas em ciência, saúde e espiritualidade. Ciência e Cultura, São Paulo, 68(1). https://doi.org/10.21800/2317-66602016000100016

Moutinho, I. L. D. et al. (2017). Depression, stress and anxiety in medical students: A cross-sectional comparison between students from different semesters. Rev. Assoc. Med. Bras., São Paulo, 63(1), 21-28. https://doi.org/10.1590/1806-9282.63.01.21

Naseem, S., Orooj, F., Ghazanfar, H., \& Ghazanfar, A. (2016). Qualidade de vida de estudantes de medicina paquistaneses em uma instituição privada. $J$ Pak Med Assoc, 5, 579-583.

Pargament, K. I. (1997). The Psychology of Religion and Coping: Theory, Research, Practice. Guilford Press, New York.

Pagnin, D., \& De Queiroz, V. (2015). Comparison of quality of life between medical students and young general populations. Education for Health, 28(3), 209. https://doi.org/10.4103/1357-6283.178599

Petrine, A. C., Margato, G., \& Junior, G. (2013). Avaliação da percepção da qualidade de vida de jovens universitários: comparativo entre graduandos do turno diurno e noturno. Revista Brasileira de Qualidade de Vida, 5(3), 1-8. https://doi.org/10.3895/S2175-08582013000300001

Quaggio, C. M. D. P., Virmond, M. D. C. L., \& Guimarães, H. C. Q. C. P. (2014). Qualidade de vida da pessoa tratada da hanseníase. Hansen. int, 36-46. Retrieved from: http://hi.ilsl.br/detalhe_artigo.php?id=12347\#

Ramos-Dias, J. C., Libardi, M. C., Zillo, C. M., Igarashi, M. H., \& Senger, M. H. (2010). Qualidade de vida em cem alunos do curso de Medicina de Sorocaba-PUC/SP. Revista Brasileira de Educação Médica, 34(1), 116-123. https://doi.org/10.1590/S0100-55022010000100014

Rosa, C. S., Arronqui, G. V., Lacava, R. M. V. B., Magalhães, S. M. F., \& Goldman, R. E. (2012). Qualidade de vida dos graduandos de enfermagem: análise da produção científica. Revista Brasileira de Qualidade de Vida, 4(2), 38-49. https://doi.org/10.3895/S2175-08582012000200004

Rosmarin, D. H., Pargament, I. K., \& Koenig H. G. (2020) Spirituality and mental health: challenges and opportunities. The Lancet. February 20. https://doi.org/10.1016/S2215-0366(20)30048-1

Rossi, A. M., Perrewé, P. L., \& Meurs, J. A. (2013). Stress e qualidade de vida no trabalho: melhorando a saúde e o bem-estar dos funcionários. São Paulo: Atlas.

Santana, L. D. L., Sarquis, L. M. M., Miranda, F. M. D. A., Kalinke, L. P., Felli, V. E. A., \& Mininel, V. A. (2016). Indicadores de saúde dos trabalhadores da área hospitalar. Revista Brasileira de Enfermagem, 69(1), 30-39. https://doi.org/10.1590/0034-7167.2016690104i

Saravanan, C., \& Wilks, R. (2014). Medical students' experience of and reaction to stress: the role of depression and anxiety. Scientific World Journal. https://doi.org/10.1155/2014/737382

Schleich, A. L. R. (2006). Integração a educação superior e satisfação acadêmica de estudantes ingressantes e concluintes: um estudo sobre relações. Repositório da Produção Científica e Intelectual da UNICAMP. Retrieved from http://repositorio.unicamp.br/handle/REPOSIP/252706

Silva Bampi, L. N., Baraldi, S., Guilhem, D., Araújo, M. P., \& Oliveira Campos A. C. (2013). Qualidade de Vida de Estudantes de Medicina da Universidade de Brasília. Rev. Bras. Educ. Méd., 37(2), 217-25. https://doi.org/10.1590/S0100-55022013000200009

Silva, É. C., \& Heleno, M. G. V. (2012). Qualidade de Vida e Bem-Estar Subjetivo de Estudantes Universitários. Revista Psicologia e Saúde, 4(1), 69-76. https://doi.org/10.20435/pssa.v4i1.126

Strelhow, M. R. W., \& Castellá Sarriera, J. (2018). Evidências de validade do índice de religiosidade de duke (P-DUREL) entre adolescentes. Avaliação psicológica. São Paulo., 17(3), 330-338. https://doi.org/10.15689/ap.2018.1703.14630.06

Tassini, C. C., Val, G. R. D., Candido, S. D. S., \& Bachur, C. K. (2017). Assessment of the lifestyle of university students in the healthcare area using the Fantastic Questionnaire. International Journal of Cardiovascular Sciences, 30(2), 117-122. https://doi.org/10.5935/2359-4802.20170024

Taunay, T. C. D. E., Gondim, F. D. A. A., Macedo, D. S., Moreira-Almeida, A., Gurgel, L. D. A., Andrade, L. M. S., \& Carvalho, A. F. (2012). Validação da versão brasileira da escala de religiosidade de Duke (DUREL). $\begin{array}{lllll}\text { Archives of Clinical Psychiatry (São Paulo), } & 39(4), & \text { 130-135. }\end{array}$ 
https://doi.org/10.1590/S0101-60832012000400003

Velarde-Jurado, E., \& Avila-Figueroa, C. (2002) Evalución de la calidad de vida. Salud Pública de México, 44(4). https://doi.org/10.1590/S0036-36342002000400009

WHOQOL-BREF. (1996). Introduction, administration, scoring and generic version of the assessment. Programme on mental health, 6. Retrieved from: http://www.who.int

Zhang, Y., Qu, B., Lun, S., Wang, D., Guo, Y., \& Liu, J. (2012). Quality of life of medical students in China: a study using the WHOQOL-BREF. PloS one, 7(11), e49714. https://doi.org/10.1371/journal.pone.0049714

\section{Copyrights}

Copyright for this article is retained by the author(s), with first publication rights granted to the journal.

This is an open-access article distributed under the terms and conditions of the Creative Commons Attribution license (http://creativecommons.org/licenses/by/4.0/). 